\title{
SURVEILLANCE OF MICROBIAL FLORA FOR INFERTILITY COUPLES IN AN INDIAN TERTIARY CARE TEACHING HOSPITAL
}

\author{
SUJATA PRIYADARSINI MISHRA ${ }^{1}$, RATNA PANDA ${ }^{1}$, TAPAN PATNAIK ${ }^{1}$, MAHESH CHANDRA SAHU ${ }^{2 *}$
}

${ }^{1}$ Department of Obstetrics and Gynaecology, Institute of Medical Science and SUM Hospital, Siksha 0 Anusandhan University, Bhubaneswar, Odisha, India. ${ }^{2}$ Directorate of Medical Research, Institute of Medical Science and SUM Hospital, Siksha O Anusandhan University, Bhubaneswar, Odisha, India. Email: mchsahu@gmail.com

Received: 17 January 2017, Revised and Accepted: 30 January 2017

ABSTRACT

Objective: Infertility has been known to cause serious social and emotional problems in India. Microorganisms may be a primary cause for this infertility. This study was carried out to know the prevalence of microorganisms in the infertility couples of a tertiary caring teaching hospital.

Methods: One thousands of couples were screened for the infertility test presented at the outpatient Department of Obstetrics and Gynaecology. The suspected infertility couples were tested for microbial contamination in their reproductive sample. Simultaneously, the demographic data of all patients were documented, and all the data were analyzed with SPSS 20 software.

Result: From one thousand couples, 288 couples were found infertility symptoms, whereas $67.71 \%$ were primary infertility problems and rest were secondary. It is due to male factor (27.08\%), female factor (50\%), and both (4.86\%) but 18.05 were unexplained. From vaginal swabs, 186 and semen 145 microbial colony were grown. However, Chi-square $\left(\chi^{2}\right)$ showed that there is no significant difference between the growth of microbial colony from semen or vaginal swap as $\mathrm{p}=0.06$. Eight varieties of bacteria (387) and Candida albicans (37) were documented.

Conclusion: With respect to older ages of the infertile couples, it is more chances to infections. Antibiotic should be prescribed to primary infertility couples and infections can be avoided the cross transmission during intercourse.

Keywords: Primary infertility, Candida, Semen, Antibiotic, Vaginal swab.

(C) 2017 The Authors. Published by Innovare Academic Sciences Pvt Ltd. This is an open access article under the CC BY license (http://creativecommons. org/licenses/by/4. 0/) DOI: http://dx.doi.org/10.22159/ajpcr.2017.v10i4.16932

\section{INTRODUCTION}

In India, childless couples are suffered both mentally and socially to live. The psychological problem is associated with the increase of infertility duration. However, the reason behind these infertile couples is varied from couple to couple. The cause may be male factor, female factor, both male and female factors or sometimes idiopathic [1]. In about $60 \%$ of married couples, $90 \%$ would achieve pregnancy in 12 months, and $95 \%$ would be able to achieve pregnancy in 18-24 months [2]. Failure to achieve pregnancy at the end of this period is not a definite criterion to arrive at a diagnosis of infertility as the age of the woman must be taken into consideration. Female fertility is at its peak between the ages of 18 and 24 years, while, it starts to decline after the age of 34 years [3].

Infertility in the female may be traced to age, tubal factor, ovarian factor, and uterine factor among others [4]. Male infertility, a common problem worldwide, is a neglected reproductive health issue in India [3]. It is estimated that the male factor accounts for $20-50 \%$ of the cause of infertility in different parts of India [4,5]. Male infertility may actually occur following the occlusion of the vas deferens [6]. Similarly, a high level of hyperprolactinemia has been associated with male infertility $[7,8]$. Also associated with the condition is the antispermantibodies [9] as well as genital infections [10,11]. Studies have equally revealed a higher concentration of aflatoxin in infertile India males than those in the fertile control, indicating that aflatoxin may contribute significantly to male infertility [12]. The WHO [13] minimal criteria for normal semen include on the average a volume of $1.5 \mathrm{ml}$; minimal count of 20 millions sperms $/ \mathrm{ml}$; sperm motility of $60 \%$, and no blood cells. Microbial infections have been reported to reduce sperm viability. Chlamydia trachomatis infections lead to blockage in the epididymis, following chronic epididymis and variably lead to azoospermia [14]. However, Ureaplasma urealyticum infections which induce leukocytospermia consequently lead to sperm damage, decrease sperm numbers, and invariably impaired sperm motility [15].

Vaginal infection is a common disease of women. Causes of vaginal discharge include physiological, infective (e.g., bacterial vaginosis, candidiasis, trichomoniasis), and non-infective (foreign bodies, cervical ectopy, and genital tract malignancy) [1]. Although after 40 years, there is a fall in estrogen production. An estrogen deficient state in vagina and the immune-compromised status due to diabetes or other associated factors can lead to growth of abnormal flora which may, in turn, lead to infections. Bacterial vaginal infections are often least understood, and empirical antifungal therapy for any vaginal infection without high vaginal swab (HVS) culture is still in practice. Normal vaginal $\mathrm{pH}$ in women of reproductive age is acidic; $\mathrm{pH}$ is normally $\leq 4.5$. In bacterial vaginosis and infection with trichomonas vaginalis, vaginal $\mathrm{pH}$ is elevated $>4.5$. In vaginal candidiasis, vaginal $\mathrm{pH}$ is $\leq 4.5$. Women of reproductive age with vaginal discharge should have a HVS cultured if, postnatal or post miscarriage, vaginitis without discharge, pre or post gynecological surgery, pre or post termination of pregnancy, symptoms not characteristic of bacterial vaginosis were seen [16-19]. In this study, we have screened to the infertile couples whether the microbiota is the primary cause also documented the demographic data of the couples.

\section{METHODS}

This is a prospective study and carried out form January 2012 to December 2015 and approved from our Institutional Ethics Committee. A total of 1000 couples were screened for infertile, and 288 were enrolled for this study. For the females, HVSs are collected. While for the corresponding males (spouses), semen samples were collected using the masturbation method. All semen samples were sent to the laboratory within 15 minutes of collection and analyzed using the 
WHO criteria. [13] The endocervical swabs or high vagina swabs were subjected to standard microbiological analysis. All the samples were grown in specific medium such as nutrient agar (NA), blood agar, chocolate agar, and cystine lactose electrolyte deficient agar for proper growth of bacteria and suborders dextrose agar, potato dextrose agar for fungi. Then, the colonies were identified by CLSI guideline, and with previous methods, i.e., all specimens were inoculated onto NA, MacConkey agar, and blood agar by streaking, and the plates were incubated aerobically at $37^{\circ} \mathrm{C}$ for $24 \mathrm{hrs}$. Discrete colonies were picked from the growth and subcultured to obtain pure colonies (Fig. 1), and biochemical tests were carried out.

In addition, the picked discrete colonies were Gram-stained, and thereafter, the consequent biochemical tests were done for the identification of microbiota with previous methods [18-30].

\section{RESULTS}

A total number of 1000 couples studied and documented the demographic data and cause of infertility. Among the 1000 couples, 712 couples have no infertility symptoms, whereas 288 couples had infertility symptoms (Table 1). Out of 288 infertility couple, 195 primers, 93 were secondary. With questioner, it was revealed that $44.8 \%$ infertility couples were suffered since $<5$ years whereas $55.2 \%$ suffered $>10$ years. With medical tests, it was revealed that $27.08 \%$ were suffered with malefactors and $50 \%$ were revealed futures. About $4.86 \%$ were suffered both husband and wives. However, $18 \%$ of couples were not found any reasons. Among the couples, $9.02 \%$ husbands were taken medication for their infertility management, and $57.98 \%$ females were taken management for their infertility (Table 1).

All the infected couples are divided into their respective ages. It was revealed that in females, i.e., the wives are more infected as compare to the female (Tables 2 and 3).

In wives, the rate of infections increased in the older age groups as compared to elders. The two-tailed $\mathrm{p}=0.4160$ and by conventional criteria, this difference is considered to be not statistically significant. Hence, the organisms are found in equally in both husband and wives. In wives, at the age of the more than 40 , there was more chance to infections (Table 2). In husbands, a total of 145 colonies are identifies. From the 145 colonies, 219 colonies were found in the age group on 20-39 years. Younger age group had less number of collies as compared to the older age groups (Table 3). All the samples of infertile couples were screened for microbial growth. Among the 288 couples, the

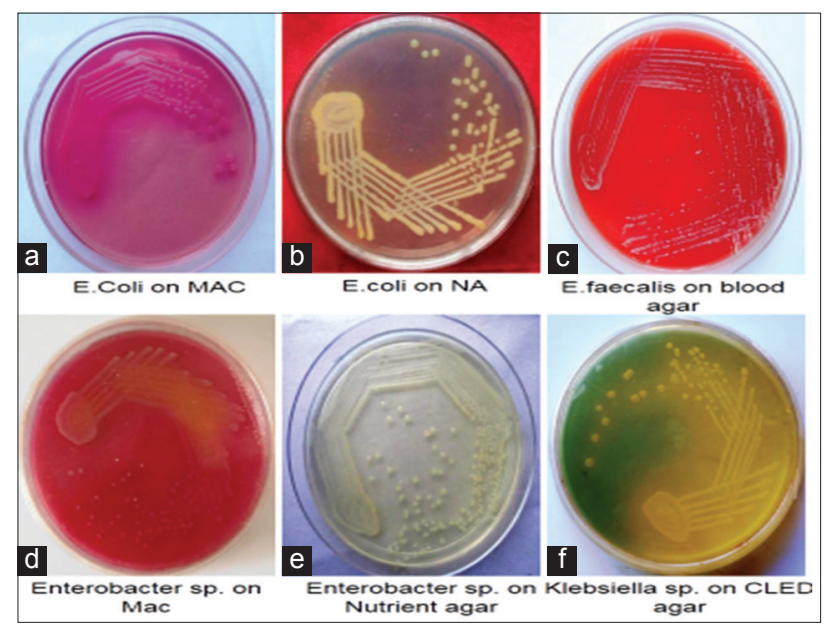

Fig. 1: Pure culture of isolated bacteria by strict plate methods. (a) Escherichia coli on MacConkey agar (MAC), (b) E. coli on nutrient agar (NA), (c) Enterococcous faecalis on blood agar, (d) Enterobacter sp. on MAC, (e) Enterobacter sp. on NA, (f) Klebsiella sp. on cystine lactose electrolyte deficient agar samples of 186 wives and 145 husbands were infected with microbial colony (Table 4). From the chi-square, it was revealed that the $\mathrm{p}$ value was more than 0.05 . Hence, it is equally distributed in both husbands and wives (Table 4).

From the growth of the microbial colony, it was revealed that there is no any difference between the growth of organisms in the same couples with different couples as $\mathrm{p}$ was more than 0.05 from the Chi-square test (Table 5).

A total number of 414 microbial colonies are observed in this study. Among them, 37 Candida albicans and rest 387 bacterial colonies were revealed. Among the bacterial colonies, Escherichia coli was highest frequency (113), and Staphylococcus aureus was next to E. coli. Only, 3 Streptococous sp. were found in this study (Table 6).

\section{DISCUSSION}

In our study, E. coli arguably the dominant organism implicated in primary infertility; among males and females alike. With a prevalence rate of $27.29 \%$ isolates from the samples of infertile couple's culture, it clearly surpasses $S$. aureus which had a prevalence of $22.71 \%$ whereas $21.01 \%, 16.67 \%, 8.94 \%, 3.14 \%, 1.21 \%, 0.97 \%$, and $0.72 \%$ were found for Pseudomonas sp., Coagulase negative Staphyloccci, C. albicans, Klebsiella sp., Proteus sp., Enterococcous faecalis, and Streptococcus sp.,

Table 1: Characteristics of infertility among the couples

\begin{tabular}{ll}
\hline Variables/characteristics & $\mathbf{n}(\%)$ \\
\hline Presence of infertility among couples & \\
Absent & $712(71.2)$ \\
Present & $288(28.9)$ \\
Type of infertility among couples (n=288) & $195(67.71)$ \\
$\quad$ Primary & $93(32.30)$ \\
Secondary & \\
Duration of infertility (in years) & $129(44.80)$ \\
$\quad<5$ years & $159(55.20)$ \\
$>10$ & $78(27.08)$ \\
Causes of infertility & $144(50.00)$ \\
Male factors & $14(4.86)$ \\
Female factor & $52(18.05)$ \\
Both & \\
Idiopathic & $26(9.02)$ \\
Receiving previous management for infertility & $167(57.98)$ \\
Husbands & \\
Wives &
\end{tabular}

Table 2: Distribution of microbial isolates in relation age of wives

\begin{tabular}{llll}
\hline Age range & Number examined & Number infected & Percent \\
\hline$<20$ & 17 & 2 & 11.765 \\
$20-29$ & 116 & 72 & 62.069 \\
$30-39$ & 149 & 107 & 71.812 \\
$>40$ & 6 & 5 & 83.333 \\
Total & 288 & 186 & 64.583 \\
\hline
\end{tabular}

Table 3: Distribution of microbial isolates in relation age of husbands

\begin{tabular}{llll}
\hline Age of husbands & $\begin{array}{l}\text { Number } \\
\text { examined }\end{array}$ & Number infected & Percent \\
\hline$<30$ & 11 & 2 & 18.182 \\
$30-39$ & 103 & 56 & 54.369 \\
$40-49$ & 117 & 61 & 52.137 \\
$50-59$ & 44 & 17 & 38.636 \\
$>60$ & 13 & 9 & 69.231 \\
Total & 288 & 145 & 50.347 \\
\hline
\end{tabular}


Table 4: Number of colony observed from respective couples

\begin{tabular}{lllll}
\hline Couple & Mixed colony & $\begin{array}{l}\text { Single microbial } \\
\text { isolate }\end{array}$ & No growth & Total \\
\hline Wife & 122 & 64 & 102 & 288 \\
Husband & 97 & 48 & 143 & 288 \\
Total & 219 & 112 & 145 & 376 \\
\hline
\end{tabular}

Table 5: Number of same colony observed in both husbands and wives

\begin{tabular}{llll}
\hline $\begin{array}{l}\text { Samples } \\
\text { from couple }\end{array}$ & Same couple & Different couple & Total \\
\hline Growth & 182 & 37 & 219 \\
No growth & 37 & 108 & 145 \\
Total & 219 & 145 & 364 \\
\hline
\end{tabular}

Table 6: Frequency of microbial isolated from the couples

\begin{tabular}{lll}
\hline Microbial isolates & $\begin{array}{l}\text { Microbial isolates in } \\
\text { frequency } \mathbf{( n = 4 1 4 )}\end{array}$ & $\begin{array}{l}\text { Percentage of } \\
\text { Microbial isolated }\end{array}$ \\
\hline E. coli & 113 & 27.29 \\
S. aureus & 94 & 22.71 \\
Pseudomonas spp. & 76 & 21.01 \\
Coagulase negative & 69 & 16.67 \\
Staphylococci & & \\
C. albicans & 37 & 8.94 \\
Klebsiella spp. & 13 & 3.14 \\
Proteus spp. & 5 & 1.21 \\
Enterobacter spp. & 4 & 0.97 \\
Streptococcus spp. & 3 & 0.72 \\
\hline
\end{tabular}

E. coli: Escherichia coli, S. aureus: Staphylococcus aureus, C. albicans: Candida albicans

respectively. It is pertinent to note that $E$. coli, the most prevalent Gramnegative organism implicated in urinary tract infection [11], is not the dominant cause of primary infertility in females. Its prevalence rate of $15.5 \%$ among isolates from endocervical swab, $19.4 \%$ of isolates from HVS places it behind both Klebsiella spp. and Proteus spp. as the dominant Gram-negative bacterial isolated from these cases of primary infertility. It is important to highlight the fact that ofloxacin, a secondgeneration fluoroquinolone is effective in the management of these infections. The study shows that basically the same group of organisms is responsible for infertility among the different couples; however, more species of bacteria were isolated from the male semen cultures. $S$. aureus and Klebsiella spp. were isolated more when compared to the other organisms. A statistical (Chi square) test indicate that there is a significant difference at $\mathrm{p}<0.0001$ when bacteria is compared with fungi as the predominant cause of primary infertility among couples.

It is particularly difficult to define abnormal genital tract flora in infertile women. The pathogenic role of specific microorganisms in the vagina as risk factors for spontaneous preterm birth (S-PTB) varies according to the investigators because microorganisms commonly found in the lower genital tract are those that are most frequently isolated from patients with intrauterine infections. The colonization rate of microorganisms in the vagina could be affected by not only technical factors, such as detection method and sampling site but also internal and external factors of each individual [31]. Possible racial/ethnic differences in the composition of the normal vaginal microflora also exist. Usui et al. [32] reported that absence of vaginal lactobacilli was a better predictor of S-PTB at $<33$ weeks of gestation than the presence of Mycoplasma hominis, but its sensitivity and positive predictive value were no more than $28 \%$ and $25 \%$, respectively. Breugelmans et al. [33] reported that there was no significant correlation between the presence of abnormal vaginal flora and S-PTB, and the risk of S-PTB increased when Ureaplasma species was associated with an abnormal vaginal flora.

\section{CONCLUSION}

The study has shown the prevalent microbial cause of infertility in our region. More importantly, it highlights the fact that these organisms are common, in the different anatomical region of the female, responsible, or involved in reproduction. Although the males also have similar organisms isolated from the semen; a few other organisms were solely isolated from the males. This isolates may later be involved in cross-transmission as the couple engaged in intercourse, further compounding the problem and antibiotics will avoid these infections. We, therefore, suggest therapeutic managements strategies of couples with primary infertility to include antibiotics and couples should be managed together to avoid cross-transmission.

\section{REFERENCES}

1. Agboola A. Infertility and subinfertility. In: Akin A, editor. Textbook of Obstetrics and Gynaecology. Vol. 1. Ibadan: Heinman Educational Books; 2004. p. 174-6.

2. Collier J, Longmore M, Scally P. Infertility: Causes and test. In: Collier J, Longmore M, Scally P, editors. Oxford Handbook of Clinical Specialties. $6^{\text {th }}$ ed. Oxford: Oxford University Press; 2003. p. 58-9.

3. Okonofua F, Menakaya U, Onemu SO, Omo-Aghoja LO, Bergstrom S. A case-control study of risk factors for male infertility in Nigeria. Asian J Androl 2005;7(4):351-61.

4. Chukudebelu WO, Esege N, Megafu U. Etiological factors in infertility in Enugu, Nigeria. Infertility 1979;2(2):193-200.

5. Esimai OA, Orji EO, Lasisi AR. Male contribution to infertility in Ile-Ife, Nigeria. Niger J Med 2002;11(2):70-2.

6. Ojengbede OA, Omonria WE, Ladipo OA. Screening for obstruction of the vas deferens in Nigerian men with azoospermia using the alphaglucosidase reaction in semen. Afr J Med Med Sci 1992;21(2):79-81.

7. Adejuwon CA, Ilesanmi AO, Ode EO. Hyperprolactinaemia as a cause of male infertility in Ibadan. West Afr J Med 1999;18:17-9.

8. Onemu SO, Ibeh N. Studies on the significance of positive bacterial semen cultures in male fertility in Nigeria. Int Fertil Women Med 2001;46:210-4.

9. Olooto WE. Infertility in male; Risk factors, causes and management-A review. J Microbiol Biotechnol Res 2012;2(4):641-5

10. Ohri M, Prabha V. Isolation of sperm agglutinating factor from Staphylococcus aureus isolated from a woman with unexplained infertility. Fertil Steril 2005; 84, 1539-41.

11. World Health Organization. WHO Laboratory Manual for the Examination of Human Semen and Sperm-Cervical Mucus Interaction. Cambridge: Cambridge University Press; 1999.

12. Ochsendorf FR, Özdemir K, Rabenau H, Fenner T, Oremek R, Milbradt R, et al. Chlamydia trachomatis and male infertility: Chlamydia-IgA antibodies in seminal plasma are C. Trachomatis specific and associated with an inflammatory response. J Eur Acad Dermatol Venereol 1999;12(2):143-52.

13. Mitchell $\mathrm{H}$. Vaginal discharge--causes, diagnosis, and treatment. BMJ 2004;328(7451):1306-8.

14. Royal College of Obstetricians \& Gynaecologists; British Association for Sexual Health and HIV. The management of women of reproductive age attending non-genitourinary medicine settings complaining of vaginal discharge. J Fam Plann Reprod Health Care 2006;32(1):33-42.

15. Caillouette JC, Sharp CF Jr, Zimmerman GJ, Roy S. Vaginal pH as a marker for bacterial pathogens and menopausal status. Am J Obstet Gynecol 1997;176(6):1270-5.

16. Radcliffe K, Jusuf I, Cowan FM, Fitzgerald M, Wilson J. UK national guidelines on sexually transmitted infections and closely related conditions. Sex Transm Infect 1999;75:S1.

17. Blackwell AL, Thomas PD, Wareham K, Emery SJ. Health gains from screening for infection of the lower genital tract in women attending for termination of pregnancy. Lancet 1993;342(8865):206-10.

18. Dubey D, Rath S, Sahu MC, Rout S, Debata NK, Padhy RN. A report on infection dynamics of inducible clindamycin resistance of Staphylococcus aureus isolated from a teaching hospital in India. Asian Pac J Trop Biomed 2013;3(2):148-53.

19. Rath S, Dubey V, Sahu MC, Debata NK, Padhy RN. Surveillance of multidrug resistant Escherichia coli in community and a hospital from Odisha. Asian Pac J Trop Dis 2014;4(2):140-9. 
20. Dash A, Sahu K, Senapati JN, Debata NK, Sahoo J, Raulo BC, et al. Surveillance of antibiotic sensitivity and resistance pattern of bacteria isolated from orthopaedic wound discharge. Int J Pharm Sci Rev Res 2016;36(1):208-11.

21. Sahu MC, Patnaik R, Padhy RN. In vitro combination-efficacy of ceftriaxone and leaf extract of Combretum albidum G. Don against multidrug resistant Pseudomonas aeruginosa and host-toxicity testing with human lymphocytes. J Acute Med 2014;4(1):26-37.

22. Sahu MC, Rath S, Dubey D, Debata NK, Padhy RN. Multidrug resistance of Pseudomonas aeruginosa as known from surveillance of nosocomial and community infections in an Indian teaching hospital. J Public Health 2012;20(4):413-23.

23. Sahu MC, Dubey D, Rath S, Panda T, Padhy RN. Monograph: In vitro efficacy of 30 ethnomedicinal plants used by Indian aborigines against 6 multidrug resistant gram-positive pathogenic bacteria Asian Pac J Trop Dis 2015;5(2):136-50.

24. Sahu MC, Padhy RN. Bayesian evaluation of two conventional diagnostic methods for pathogenic fungal infections. J Acute Med 2014;4(3):109-19

25. Sahu MC, Debata NK, Padhy RN. In vitro efficacy of Butea monosperma Lam. Against 12 clinically isolated multidrug resistant bacteria. Asian Pac J Trop Dis 2013;3(3):217-26.

26. Uh Y, Choi SJ, Jang IH, Lee KS, Cho HM, Kwon O, et al. Colonization rate, serotypes, and distributions of macrolide-lincosamide- streptogramin B resistant types of group B streptococci in pregnant women. Korean J Clin Microbiol 2009;12(4):174-9.

27. Bayraktar MR, Ozerol IH, Gucluer N, Celik O. Prevalence and antibiotic susceptibility of Mycoplasma hominis and Ureaplasma urealyticum in pregnant women. Int J Infect Dis 2010;14(2):e90-5.

28. Donati L, Di Vico A, Nucci M, Quagliozzi L, Spagnuolo T, Labianca A, et al. Vaginal microbial flora and outcome of pregnancy. Arch Gynecol Obstet 2010;281(4):589-600

29. Divyashanthi CM, Adithiyakumar S, Bharathi N. Study of prevalence and antimicrobial susceptibility pattern of bacterial isolates in a tertiary care hospital. Int J Pharm Pharm Sci 2014;7(1):185-90.

30. Jyothi P. Antibiotic sensitivity pattern of Citrobacter spp. isolated from patients with urinary tract infections in tertiary care hospital in South India. Int J Pharm Pharm Sci 2014;7(1):252-4.

31. Hay PE, Morgan DJ, Ison CA, Bhide SA, Romney M, McKenzie P, et al. A longitudinal study of bacterial vaginosis during pregnancy. $\mathrm{Br} \mathrm{J}$ Obstet Gynaecol 1994;101(12):1048-53.

32. Lee SE, Romero R, Kim EC, Yoon BH. A high Nugent score but not a positive culture for genital mycoplasmas is a risk factor for spontaneous preterm birth. J Matern Fetal Neonatal Med 2009;22(3):212-7.

33. Choi SJ, Park SD, Jang IH, Uh Y, Lee A. The prevalence of vaginal microorganisms in pregnant women with preterm labor and preterm birth. Ann Lab Med 2012;32:194-200. 